\title{
Study on the Application of Power Marketing Inspection in Marketing Management Information System
}

\author{
Yichao Zheng \\ State Gird Jiangxi Electric Power Research Institute
}

Keywords: Power marketing inspection; Management of electricity fees; Inspection management

\begin{abstract}
With the development of social economy as well as science technology, power enterprises are paying more attention to power marketing management so as to raise enterprises' core competitiveness. At present, marketing inspection has been widely applied to power management, which is good for conducting marketing inspection, reducing power marketing errors, improving quality of service, decreasing customer complaint, promoting business management and publicizing enterprise image. It is an important means for maximizing business interest with certain active effect on power management. However, there are many problems existing in Chinese power marketing inspection with serious effect on the development of Chinese power enterprises, which need to be solved necessarily. In this paper, the existing problems and resolutions are proposed for current power marketing inspection with certain related suggestions to administrate and control current power marketing inspection so as to standardize power industry and promote the marketing efficiency in power market.
\end{abstract}

\section{Introduction}

The power marketing inspection is mainly to effectively monitor the whole business process and activities of power marketing and to avoid some common operating risks to some extent, which can reduce economic lost and errors in power marketing activities so as to improve the standard of power marketing management. Thus it will play an important role in increasing economic effect. The application of marketing inspection in marketing management information system embodies the importance and position of marketing inspection in power marketing management completely. The necessity of power marketing inspection lies in that it is a business monitoring process of marketing business and service. By conducting concentrated online inspection and sample inspection on marketing business and service as well as timely and online monitoring and analysis on key indicators, quality of work and service, the overall quality of work can be promoted constantly. Besides, since it is closely related to the direct interest of power enterprises, it play an especially important role in the power marketing management by applying marketing inspection.

In this paper, problems existing in current power marketing inspection as well as countermeasures are introduced to provide related suggestions for current power marketing inspection management and control so as to standardize industrial behaviors and improving marketing efficiency.

\section{Main Work of Inspection}

Power inspection is an important section of marketing management, including inspection of power supply, method of calculation, inspection on customers with altered power business, inspection on the release of working tickets as well as the validity. Meanwhile, it aims to inspect the rationality of power property, power price and errors and major accidents during marketing, and if customers use power legally or not and so on. Power inspection is an important guarantee for implementing the state power policies with effective effect of supervision, and it also plays an role in monitoring and restraining various sections of power marketing. In order to promote the standard and quality of power marketing and realize a stable development, the function of power inspection should be valued necessarily to perfect the power inspection system. At present, power enterprises have become demutualized and commercial. The power enterprises can constantly realize their goals 
only if they carry out internal reform and perfect power marketing inspection system. The power inspection should adapt to the reform and development by changing traditional concepts, ensuring the efficiency of monitoring, offering qualified service and constantly expand inspection range and aspects by promoting service ideas of inspection.

\section{Analysis on the Status of Power Marketing Management Information System}

The power marketing management information system is an important platform supporting the implementation, record and settlement of power business as well as a database for customers' information and materials. During the usage of power marketing management information system, in order to reduce errors, the marketing inspectors should select the data carefully with analysis and recognition by making full use of the data of marketing information system so as to discover problems timely with quick feedback. In this way, the administrative standard of marketing inspection can be constantly improved to be professional and scientific, which is a major action and necessary trend in promoting the administrative work of power marketing.

Power marketing business is of various kinds with wide ranges and strong timeliness. Therefore, administrators of power marketing can't master the altering situation and work quality in the whole marketing comprehensively, which greatly reduces the timeliness of power marketing administration; and meanwhile it proposes more complicated technical requirements for information system for higher efficiency.

At present, power marketing business is of strong continuity with more sections generally, which is bad for adapting to market demands. Marketing management information system based on this requirement is lack of materials with more operating risks such as delayed approval. The wrong execution of power price resulted by system information maintenance and untimely update as well as some other technical risks such as desynchronic transaction data and implement statistic data are all current problems existing in power marketing business.

\section{Administration System of Inspection Should be Formulated with Serious Process of Inspection Responsibilities}

At present, one of the main reasons for problems existing in power marketing inspection is that power enterprises are lack of scientific and standard administrative provisions with ineffective supervision on power marketing inspection. Some improvements are made in this paper to solve the problems.

Selection of Inspectors Should be Strict to Adjust the Structure of Inspectors. As an institute of power execution, inspectors of power marketing should have higher qualities than other power workers, so more strict and detailed standards should be formulated for the selection with more concrete selection steps to ensure the openness and fairness of the selection.

Behavioral Norms for Power Marketing Inspection Should be Formulated. In practical work, power marketing inspectors have no obvious symbols with disordered costumes, simple means and tough attitudes. Thus, their behaviors should be standardized systematically. In detail, they should wear unified costumes to change their images. Meanwhile, the inspection process should also be standardized systematically.

Objection System for Power Marketing Inspection Should be Established and Perfected. Power inspectors usually act toughly in their work with inefficient ideological importance. They usually punish those who steal power without allowing any objection, which can arouse suspect among public. Therefore, power marketing inspection should standardize their work procedure by establishing objection system.

\section{Conclusion}

In current situation, the marketing management effect should be raised by improving power marketing inspection, strengthening the administration and controlling functions of power 
marketing inspection and consolidating basic administrative work based on modern marketing technologies so as to avoid major accidents and lower business errors. Thus the marketing management level can be improved constantly by establishing sound power supply order to meet customers' demand. Besides, the power marketing inspection is inevitable for perfecting and improving the balanced system of supervision. In addition, Quality of power marketing inspection can directly affect the economic effect, administrative effect and social effect of power supply.

\section{References}

[1] Powermarketing E. Reform: Electricity Outage Sparks Outrage [J]. Waste Management \& Environment, 2009, 20.

[2] Shahidehpour M, Yamin H, Li Z. Market Operations in Electric Power Systems [J]. Journal of Scheduling, 2002.

[3] Wei-hua. Electric Power Marketing based on intelligence decision tree and artificial Neural Network [J]. Journal of Communication \& Computer, 2008, 5(1):27-30.

[4] Long J X. Implementation of Decision Support System for Electric Power Marketing [J]. Applied Mechanics \& Materials, 2011, 63-64:168-171.

[5] Danton, Ray. Electric power marketing provides corporate “cross - training” [J]. Natural Gas, 1996, 12(11):16-18.

[6] Wang S T. Theoretical Study and Empirical Analysis of Electric Power Marketing Audit Based on CPM [J]. Shaanxi Electric Power, 2009.

[7] Goetsch H W. Marketing audit questions [J]. Marketing News, 1983.

[8] Odote B O, Robby W O. Marketing Audit and Performance: A Case of Parastatals [M]. LAP LAMBERT Academic Publishing, 2013.

[9] Francis J. HOW TO SURVIVE A MARKETING AUDIT [J]. Aba Bank Marketing, 2013.

[10]Zhao Y, Wang Y Q, Yong-Feng L I, et al. Application practice of marketing audit customer self-defined theme in Qinhuangdao Electric Power Company [J]. Power Demand Side Management, 2013.

[11]Zhu Y, Zhou W. Research of Electric Power Marketing System task decomposition on grid[C]// Computer Science and Network Technology (ICCSNT), 2012 2nd International Conference on. IEEE, 2012:1488-1492.

[12]Xiang-Qian Y U, Wang L X, Liang Y, et al. Efficient Management Mode Building of Electric Power Company Marketing Inspection[J]. Economic Research Guide, 2013. 